\title{
Algal Biofuels: A Credible Prospective?
}

\author{
Bhavish Patel, Bojan Tamburic, Fessehaye W. Zemichael, \\ Pongsathorn Dechatiwongse, and Klaus Hellgardt \\ Department of Chemical Engineering, Imperial College London, London SW7 2AZ, UK \\ Correspondence should be addressed to Klaus Hellgardt, k.hellgardt@imperial.ac.uk
}

Received 31 October 2012; Accepted 5 December 2012

Academic Editors: M. S. Abdel-Mottaleb and H. Boyer

Copyright ( 2012 Bhavish Patel et al. This is an open access article distributed under the Creative Commons Attribution License, which permits unrestricted use, distribution, and reproduction in any medium, provided the original work is properly cited.

Global energy use has reached unprecedented levels and increasing human population, technological integration, and improving lifestyle will further fuel this demand. Fossil fuel based energy is our primary source of energy and it will remain to be in the near future. The effects from the use of this finite resource on the fate of our planet are only now being understood and recognised in the form of climate change. Renewable energy systems may offer a credible alternative to help maintain our lifestyle sustainably and there are a range of options that can be pursued. Biofuels, especially algae based, have gained significant publicity recently. The concept of making biofuels, biochemicals, and by-products works well theoretically and at small scale, but when considering scaleup, many solutions can be dismissed on either economical or ecological grounds. Even if an (cost-) effective method for algae cultivation is developed, other input parameters, namely, fixed nitrogen and fresh water, remain to be addressed. Furthermore, current processing routes for harvesting, drying, and extraction for conversion to subsequent products are economically unattractive. The strategies employed for various algae-based fuels are identified and it is suggested that ultimately only an integrated algal biorefinery concept may be the way forward.

\section{Introduction}

For millennia, the only combustible fuel was wood, a biofuel. It enabled the first civilisations to flourish, powered the furnaces of the Roman Empire, and fuelled the Age of Discovery. Then, in 1698, the invention of the first practical steam engine sparked the Industrial Revolution. Biofuels were replaced by fossil fuels, initially coal and later crude oil and natural gas. Fossil fuels had the critical advantage of a significantly higher energy density $\left(45 \mathrm{MJ} \mathrm{kg}^{-1}\right.$ for crude oil compared to $15 \mathrm{MJ} \mathrm{kg}^{-1}$ for wood). The Industrial Revolution led to improved living standards and exponential population growth due to this abundance of cheap energy, eventually giving way to the modern day information revolution and globalisation.

Today we live in a world powered by fossil fuels. Global population and energy demand continue to rise rapidly. Global population is projected to increase from 6.6 billion in 2008 to 9.2 billion by 2050, coinciding with a global primary energy demand increase from $13 \mathrm{TW}$ to $28 \mathrm{TW}$ in the same time frame. This comes at a time when we have discovered that fossil fuels are not the panacea that they were once believed to be. Proven crude reserves are dwindling and the end of cheap petroleum and diesel is imminent. Conventional crude oil production peaked at 74 million barrels per day in 2004 and has been declining ever since. In addition, the combustion of fossil fuels has released trapped carbon into the atmosphere in the form of carbon dioxide $\left(\mathrm{CO}_{2}\right)$, a greenhouse gas. The present-day $\mathrm{CO}_{2}$ concentration in the atmosphere is 390 parts per million (ppm), significantly higher than the preindustrial (historic) level of $280 \mathrm{ppm}$. Consequently, the mass of atmospheric $\mathrm{CO}_{2}$ is increasing at a rate of 34 gigatonnes of $\mathrm{CO}_{2}$ per annum $\left(\mathrm{GtCO}_{2} / \mathrm{y}\right)$ [1]. In order to avoid a $2^{\circ} \mathrm{C}$ global temperature rise, which should prevent the more devastating effects of climate change, the average UK residents would need to reduce their $\mathrm{CO}_{2}$ emissions from $11 \mathrm{tCO}_{2} / \mathrm{y}$ today to $1 \mathrm{tCO}_{2} / \mathrm{y}$ by 2050 [2]. This cut is so drastic that it almost certainly implies the complete replacement of fossil fuels with alternative low carbon fuels in the transport sector. 


\section{Biofuels}

The last decade has seen massive investment in liquid biofuel alternatives to petroleum and diesel, with the USA, Brazil, and the European Union leading the way. Biofuel projects have been funded by policies such as the Renewable Transport Fuel Obligation (RTFO) in the UK, which places a requirement on liquid fossil fuel owners to mix a small percentage of biofuel with their product [3]. Globally, corn and sugarcane derived bioethanol have been the primary recipients of biofuel grants and subsidies. Not only have these first generation biofuels failed to deliver on $\mathrm{CO}_{2}$ mitigation targets, they have also contributed to a host of environmental and socioeconomic problems. This is because the world today is very different from the biofuel dominated preindustrial era: the human population is vast, arable land is limited, and energy demand is massive. The low power density of first generation biofuels results in arable surface area requirements that are impracticable for most European countries. For example, it would be necessary to cover more than one-third of the entire UK land area with rape crops to produce enough rape-seed oil to fuel the 30 million personal vehicles on the road today [2]. Even in the US Midwest, where arable land is plentiful and growth conditions are good, the use of corn and other agricultural crops to produce biofuels has come under intense scrutiny. The increased cultivation of agricultural biofuels has resulted in a partial coupling of the demand for fuel in the developed world with the demand for food in the developing world. This food versus fuel dilemma exaggerates shortages of both resources and it was partially responsible for the world food price crisis in 2008 that led to widespread malnutrition and starvation, as well as political and social unrest [4]. Developing tropical countries such as Brazil and Indonesia often face a fuel versus forest decision. Clearing primary rainforest to make way for sugarcane plantations not only devastates local biodiversity, it also damages a crucial $\mathrm{CO}_{2}$ sink [5]. African nations would be better served by using their limited water reserves to feed their respective populations rather than to grow energy crops. Biofuels also require ammonium-based fertilisers produced in the fossil fuel intensive Haber-Bosch process. For every tonne of fertiliser produced, 3.7 tonnes of carbon dioxide are emitted. These industrial fertilisers are frequently overused, triggering soil erosion, and deadly algal blooms in river estuaries. Recent wide-scope life-cycle analyses have shown that some first generation biofuels actually increase $\mathrm{CO}_{2}$ emissions once fertiliser, harvesting, processing, and land use energy costs are taken into account [6]. Even in the cases where biofuels reduce $\mathrm{CO}_{2}$ emissions, they are not the most cost-effective or the most ethical means of doing so.

Advanced biofuels have been developed to address many of the issues listed in the previous paragraph. They include the large perennial grass Miscanthus giganteus, cellulosebased fuels, and various waste to fuel initiatives. While less controversial than traditional biofuels and certainly applicable to some niche markets, advanced biofuels remain limited by the same low power density as their predecessors and are unlikely to make more than a small dent in the fossil fuel domination of transport. It is therefore hardly surprising that artificial systems for the production of transport fuels have begun to emerge. Renewable electricity generation (wind, solar photovoltaic, or nuclear) could be used to power water electrolysis, producing hydrogen for use directly as a fuel or as a reductant to generate more desirable liquid fuels such as methanol. Although renewable electrolysis systems could operate at efficiencies higher than natural photosynthesis, they would be many times more expensive [7]. It is therefore more practical to use the renewable electricity directly, although water electrolysis may play an important role as a storage technology for intermittent renewable resources. Research has also intensified in the area of artificial photosynthesis, with contributions from the fields of synthetic biology $[8,9]$, biomimetics $[10,11]$, electrochemistry $[12,13]$, and many others. The problem with this approach is not only that natural photosynthesis is extremely complex, but that many of the proteins and enzymes involved in the processes of light harvesting, water splitting, and $\mathrm{CO}_{2}$ reduction are already very efficient, having been moulded and perfected by 2.5 billion years of evolutionary pressure. Perhaps it is not time to give up on natural photosynthesis just yet.

Although intrinsically different (Table 1), simple photosynthetic microorganisms such as green algae and cyanobacteria (henceforth referred to as "algae") do photosynthesis best, but they are only now becoming recognised as a viable biofuel source. All crude oil ultimately came from algae so it is certainly plausible that future transport fuels could be obtained from the same source.

\section{Algae as a Source of Biofuel}

Photosynthesis involves the capture of solar energy by phototrophic organisms and its conversion into chemical energy and biopolymers. It is the basis for almost all life on Earth. The first stage of the photosynthetic electron transport chain is catalysed by the photosystem II (PSII) protein complex. Light-harvesting antennae within PSII capture solar energy, generating a chlorophyll radical cation and a reduced plastoquinone molecule, the strongest redox pair known in biology [14]. This electrochemical potential is passed along a series of redox active components to the thylakoid membrane, where an embedded $\mathrm{Mn}_{4} \mathrm{Ca}$ cluster oxidises water into oxygen molecules, protons, and electrons. Electrons derived from water splitting eventually create a $\mathrm{pH}$ gradient that is responsible for driving the Calvin Cycle. The Calvin Cycle, catalysed by the enzyme RuBisCO, involves the reduction of atmospheric $\mathrm{CO}_{2}$ and the subsequent production of carbohydrates such as glucose, sucrose, and starch. When energy is plentiful, surplus starch can be stored in the form of fatty acids, triglycerides (TAGs), or other lipids. In stark contrast to artificial photosynthetic systems [15], the enzymes that carry out natural photosynthesis are non-toxic; they operate at room temperature and pressure and they are based on the most common elements. These enzymes are difficult to isolate or to biomimic because 
TABLE 1: The similarities and differences between green algae and cyanobacteria [24-30].

\begin{tabular}{|c|c|c|}
\hline \multirow{2}{*}{ Similarities } & \multicolumn{2}{|l|}{ Differences } \\
\hline & Green algae & Cyanobacteria \\
\hline \multicolumn{3}{|c|}{ Physical } \\
\hline $\begin{array}{l}\text { Both are only known microorganisms, which } \\
\text { are able to produce photosynthetic oxygen as } \\
\text { well as hydrogen }\end{array}$ & Eukaryotes & Prokaryotes \\
\hline $\begin{array}{l}\text { Simple growth requirement that is sunlight, } \\
\text { water and } \mathrm{CO}_{2}\end{array}$ & Only green pigments & $\begin{array}{l}\text { Green pigment and blue pigment } \\
\text { (phycobilin) }\end{array}$ \\
\hline Able to grow on non-arable land & $\begin{array}{c}\text { Need an external intervene for example } \\
\text { sulphur-deprivation to establish anaerobic } \\
\text { condition }\end{array}$ & $\begin{array}{l}\text { Able to create the highly oxygen-reduced } \\
\text { intracellular environment by itself }\end{array}$ \\
\hline $\begin{array}{l}\text { Transformability, so possible for complex } \\
\text { genetic engineering }\end{array}$ & $\begin{array}{l}\text { Require exogenous fixed nitrogen source for } \\
\text { example } \mathrm{NH}_{4}{ }^{+}, \mathrm{NO}_{3}{ }^{-}\end{array}$ & Able to fix atmospheric nitrogen \\
\hline \multicolumn{3}{|l|}{$\begin{array}{l}\text { Biomass can be further processed to make } \\
\text { biofuels and valuable co-products }\end{array}$} \\
\hline \multicolumn{3}{|c|}{ Phothosynthesis } \\
\hline $\begin{array}{l}\text { Upper bound on photosynthetic efficiency } \\
\sim 10 \% \text { (same as that for plants) }\end{array}$ & $\begin{array}{c}\text { Contain two forms of chlorophyll that is } \\
\text { chlorophyll a and } b\end{array}$ & Only chlorophyll a present. \\
\hline \multicolumn{3}{|l|}{$\begin{array}{l}\text { Having two core photosynthetic proteins that } \\
\text { is Photosystem I and II }\end{array}$} \\
\hline \multicolumn{3}{|c|}{ Hydrogen production } \\
\hline Solar to Hydrogen efficiency $<0.05 \%$ & $\begin{array}{l}\text { By direct recombination of protons and } \\
\text { elections }\end{array}$ & $\begin{array}{l}\text { Two hydrogen production pathways. } \\
\text { (i) Side reaction of nitrogen fixation. } \\
\text { (ii) Recombination of protons and electrons }\end{array}$ \\
\hline \multirow[t]{2}{*}{$\begin{array}{l}\text { Both nitrogenase and hydrogenase are very } \\
\text { sensitive to oxygen }\end{array}$} & Only hydrogenase enzyme is involved & Nitrogenase and hydrogenase enzymes \\
\hline & $\begin{array}{l}\text { Hydrogen production is very restricted to } \\
\text { anaerobic condition }\end{array}$ & $\begin{array}{l}\text { Able to aerobically produce molecular } \\
\text { hydrogen }\end{array}$ \\
\hline
\end{tabular}

they are exceptionally unstable; they have very short lifetimes; they only function under a strict set of biological conditions. Such concerns can be overcome by using algae as microbiological factories to create, replicate, and repair photosynthetic enzymes and to eventually produce biofuels.

Eukaryotic algae harvest light efficiently because a large percentage of their cell is composed of chlorophyll. Unlike deciduous plants, which lose their leaves in the winter, algae keep their chlorophyll and remain photosynthetically active all year round. Algae do not need to grow roots, leaves, shoots, or flowers. All their energy goes into the replication and repair of their photosynthetic apparatus or into reproductive efforts that increase the cell density of the algal culture. Algae are therefore more efficient at converting sunlight into chemical energy than terrestrial plants and require a smaller geographical footprint and less water for cultivation [16]. As a result of their high photosynthetic efficiency, algal cultures grow extremely fast. They commonly double their biomass within $24 \mathrm{~h}$ and are capable of doubling times as short as $3.5 \mathrm{~h}$ during the exponential growth phase [17]. Not only do algae grow quickly, but a so a large proportion of their biomass is usable as fuel. On average, lipids constitute approximately $30 \%$ of algal biomass (this value can be as high as $80 \%$ for some genetically engineered species), compared to $5 \%$ of the biomass in the case of palm oil [17]. Algae can produce more biomass per unit time and more biomass per unit area than any other plant.

One of the main advantages of using algae is their massive biodiversity, which makes it possible to select strains for a particular geographical location or a specific purpose. Different algal strains have adapted to grow in UK soil, on the surface of the ocean, underneath desert sand, next to hydrothermal vents, and in freezing Siberian rivers. There is an optimal algal strain for every location. One potential algal application is to capture the $\mathrm{CO}_{2}$ emitted by fossil fuel combustion in power stations. To achieve this, it is necessary to select an extremophile with high temperature and low pH tolerance, as well as a very active Calvin Cycle. In some cases, nature simply does not provide the right alga for the job, or the process is not efficient enough to be economically viable. It is in these situations that genetic engineering can come to the rescue. Some model organisms, such as the green alga Chlamydomonas reinhardtii and the cyanobacterium Synechocystis sp. PCC6803 have had their genomes mapped. Since these are relatively simple unicellular organisms, it is possible to create mutants with modified physical or metabolic properties. One promising approach for improving algal biofuel production is to reduce the size of the photosynthetic light-harvesting antennae. Shorter antennae would allow each PSII complex to obtain 
only the light energy that it needs for water splitting, rather than wasting energy as heat and fluorescence [18]. If successful, this approach would increase algal cell densities and consequently the power density of any biofuels derived from those algal cultures. This is because a higher cell density implies that there are more starch, lipids, and vitamins available in a given volume.

Algal biofuel productivity is not dependent on arable land and could therefore be scaled to make a significant contribution to the global demand for fossil fuels without affecting food crops or endangering forested ecosystems [18]. This is because many algal strains can be grown in brackish or saline water. These aquatic systems also happen to contain many of the salts and other nutrients required for algal growth. Many different biofuels can be extracted from algae. The most common approach is to process the algal oil fraction into biodiesel or jet fuel. The remaining algal biomass could then be digested or anaerobically fermented to produce biogas. Although biodiesel production is possible with existing technologies, more energy, efficient and cost effective techniques are also under development. A new generation of algal biofuels, including hydrogen [19] and isoprene [20], are released as gaseous products during algal growth, making them much easier to harvest. These fuels are still in early phase research. Their current production rates are too low for commercial applications, but future rewards could be substantial. Any unusable algal biomass can also be pyrolsed to biochar, which can serve as a means of $\mathrm{CO}_{2}$ sequestration, or as a substitute for coal. These processes are discussed in Section 4.4.

3.1. Requirement for Algal Growth. All algal cultures require a set of key nutrients for healthy and effective growth. These include sources of carbon $(\mathrm{C})$, nitrogen $(\mathrm{N})$, sulphur $(\mathrm{S})$, and phosphorus $(\mathrm{P})$, as well as a number of trace metals such as iron, magnesium, and manganese. An additional important requirement is the presence of a large volume of water; algal cultures grow as suspensions in this water. As discussed previously, large-scale algal biofuel production would need to be based on saline or brackish water to avoid competition with food crops for fresh water and arable land. The carbon requirement dwarfs all other nutrient requirements. Although algae grow optimally when presented with an organic carbon source such as acetate, this is not a viable option for biofuel production. Instead, the algae should be grown under photoautotrophic conditions, where they fix inorganic atmospheric $\mathrm{CO}_{2}$ by photosynthesis. Providing an appropriate source of nitrogen is considerably more difficult and it is probably the greatest barrier to sustainable algal biofuels. Nitrogen may be plentiful in the atmosphere, but the algae require fixed nitrogen in the form of ammonia to biosynthesis nucleotides, amino acids, and proteins. The industrial Haber-Bosch process is not an option due to its high environmental cost. Fortunately, some cyanobacteria are capable of diazotrophic growth where they fix their own nitrogen via the nitrogenase enzyme. These nitrogenfixing cyanobacteria could be used to produce biofuels or grown in symbiosis with a more efficient biofuel-producing algal strain. The sulphur, phosphorus, and trace metal requirements of algae are very small, but they could turn out to be significant if algal biofuel production expands to a global scale. These nutrients therefore need to be recycled following the completion of the algal growth phase. An alternative approach is to grow algae in waste residues, such as olive mill wastewater [21]. A small dilution of pretreated wastewater could provide all the necessary nutrients for many tonnes of algal biomass.

In addition to the aforementioned nutrient demands, algae also require suitable growth conditions. These include, but are not limited to, the appropriate light intensity, mixing, temperature, and $\mathrm{pH}$ [22]. Algae have moderate light intensity requirements. Most strains are perfectly happy to grow during a cloudy day in the UK and the optimal light intensity is of the order of $100 \mathrm{Wm}^{-2}$. However, it is crucial that as many cells as possible have access to this irradiation. In the absence of mixing, algal cells on the surface of the culture would absorb too much sunlight, causing the photoinhibition of the photosynthetic machinery, while those shaded underneath would receive insufficient light to grow. Until genetically engineered algal strains with reduced light-harvesting antennae become commonplace, good mixing is absolutely crucial for the wellbeing of the algal culture, and this mixing costs energy. This creates a tradeoff between the energy spent on mixing and the surfaceto-volume ratio of the algal culture. A low surface-to-volume ratio would increase the power density of the algal biofuel, unless it comes at the cost of reduced algal growth rates [23]. Innovative photobioreactor design is addressing this and other concerns. Algae normally grow at room temperatures and at a neutral $\mathrm{pH}$, but a lot of other microorganisms also enjoy these conditions. Fungi and nonnative algal or bacterial strains frequently cause contamination in open growth ponds and even in enclosed photobioreactors. The threat of contamination could be reduced by cultivating extremophiles that grow at high temperatures or salinities. In addition to contamination, algae growing in open ponds face the threat of predation, primarily from zooplankton, as well as from larger grassers.

3.2. Scalability. While algal biofuel production may be in its infancy, algal growth for high-value product extraction is a mature and very profitable industry. High-value product manufacturers typically use the algal protein fraction to obtain valuable commodities such as vitamins, dyes, pharmaceuticals, insecticides, and various precursor chemicals [34]. It is estimated that globally 5000 tons $\mathrm{y}^{-1}$ (dry mass) of microalgae are produced predominantly for use in aquaculture and for the extraction of high-value products such as carotenoids, astaxanthin, and omega-3 fatty acids. The annual turnover of the microalgal biomass market is approximately US $\$ 1.25$ billion, which gives an average cost per kilogram of biomass as US \$250 [35]. The success of algal high value products means that some of the infrastructure required to make algal biofuels a reality that already exists. These existing photobioreactor models need to be scaled up to a level where they could grab a 
significant proportion of the vast global biofuels market and beyond. In order to exploit microalgae commercially as a viable alternative to fossil fuels, the production quantity has to increase significantly and be complemented by a similar reduction in cost [36] to entice manufacturers to also view microalgae-based fuel as a feasible income generating product. At present, there is not a single profit-making commercial facility for algae-based biofuel production; most companies are supported by government grants and subsidies. Operation of a commercial scale facility for $\mathrm{CO}_{2}$ sequestration using algae has only begun recently [37]. Other large-scale facilities are predominantly devoted to research and exploratory extension into biofuels based around highvalue product manufacturing. To comprehend potential engineering challenges, and limitations opposing global algae biofuel development, the individual processes required to obtain the end product need to be critically analysed.

\section{Algae Processing}

The four major constituents of algae processing are cultivation, harvesting, processing, and production. Unlike the first three, the last process is not generic, but unique since it depends on the type of fuel being produced. The Aquatic Species Program (ASP) at NREL [38] has extensively investigated the potential of algae as a biofuels feedstock but only on pond systems. The study concluded that large-scale algal production could be an economically competitive source of renewable energy given favourable market conditions.

4.1. Cultivation. Closed photobioreactors not only reduce the risk of contamination and predation, they also prevent evaporative losses and improve the areal productivity of the remaining algal monoculture. The production of algal biofuels places a demand for photobioreactors that operate at a very large scale, measured in hectares rather than square metres. These photobioreactors need to be constructed at minimal cost, with maximum savings on auxiliary energy demand. They should be simple to clean and maintain and they should operate over a long lifespan. A standard PBR is a multiphase system, consisting of algae, water, and a dispersed gas phase. The multifaceted system is further complicated by light radiation superimposed over these variables [39]. Good PBR design requires an understanding of the correlation between different environmental parameters, such as the fluid dynamics and the light penetration within the PBR, and the corresponding biological response. The productivity of closed PBRs primarily depends on the illumination conditions, the surface-to-volume ratio and the light-dark cycle, since these parameters govern the light dilution, light attenuation, and light mixing throughout the system [40]. The PBR size and geometry govern most of these important environmental parameters. The four commonly used PBR geometries are flat-plate reactor (Figure 1(a)), horizontal tubular reactor (Figure 1(b)), vertical-column reactor (Figure 1(c)), and the stirred-tank reactor. All the PBR geometries face a unique set of opportunities and challenges and there is as yet no clear winner for algal biofuel production.

In order to minimise material costs, large-scale PBRs will almost certainly need to be constructed from inexpensive materials such as plastic bags or sheets. Fortunately, one of the high-value products commercially extracted from cyanobacteria is the Polyhydroxyalkanoates (PHAs), polymers that are used to manufacture biodegradable plastic [34]. Cyanobacteria could therefore be used to produce their own biodegradable plastic bag PBRs. Marine systems pose the particularly daunting challenge of keeping algae in and zooplankton out, especially during rough weather conditions. On the other hand, calmer waters featuring more gentle waves would deliver free natural mixing to the algal culture. This suggests that marine algae need to be grown in protected bays or lagoons; a proposal that is likely to face heavy criticism from environmental protection groups. Manufacturers and academics are actively looking into various methods and strategies of cost reduction on various photobioreactors (Figures 2(a) and 2(b)). Algasol RenewablesSL have launched a novel and flexible polymer PBR with a fully integrated internal aeration system that lowered the production cost of algae by $10 \%$ (max scalability using a low cost material and design with the added use of internal aeration). Solix Biofuels have developed thin vertically oriented panels to extend surface area and the efficient mixing of $\mathrm{CO}_{2}$ to optimise algae growth, which is predicted to reduce production cost by half over 2-3 years [41].

To improve the process economics, it is essential to use conceptual and process modelling tools and conduct an assessment of optimised manufacturing costs. Many of the projections that have been made of expected production yields are based on small-scale experiments or include assumptions of future advances [42]. Robust industrial feasibility studies need to be carried out to understand the economics of large-scale biofuel production in order to develop and optimise process conditions that are industrially viable and environmentally and socially sustainable and enable commercialisation of algae products competitively [18].

Recently, Norsker et al. [43] have reported a promising biomass production cost for 3 different algal production systems including dewatering and operating costs at commercial scale. The three systems, namely, open ponds, horizontal tubular photobioreactors and flat panel photobioreactors, were optimised with respect to irradiation, mixing photosynthetic, efficiency, medium, and carbon dioxide costs. A price of $€ 1.28$ (US \$1.72), $€ 0.70$ (US $\$ 0.94$ ), and $€ 0.68$ (US \$0.89) per $\mathrm{kg}$ biomass was reported for the three systems, respectively. Even once cost-effective, efficient PBRs have been constructed on a sufficiently large scale, there remains the issue of scaling up the harvesting and processing techniques necessary to produce algal biofuels.

4.2. Harvesting. Mass algal cultivation requires the use of substantial quantities of water. For cost-effective downstream processing, separation of algae cells from the growth medium or an increment in cell concentration is necessary. Harvesting 


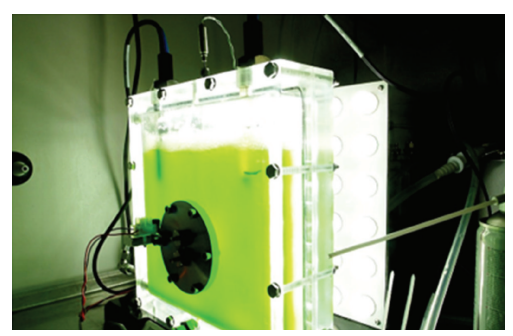

(a)

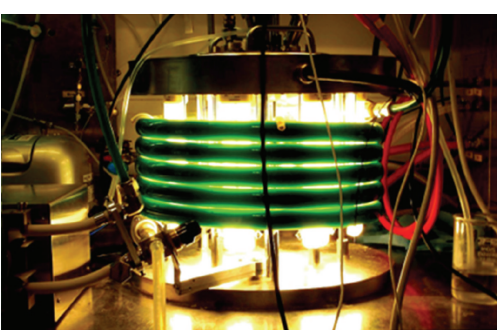

(b)

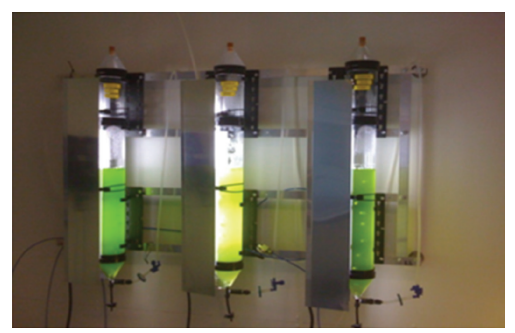

(c)

Figure 1: (a) Flat Plate Reactor, (b) Horizontal Tubular Reactor and (c) Vertical-Column Reactor.

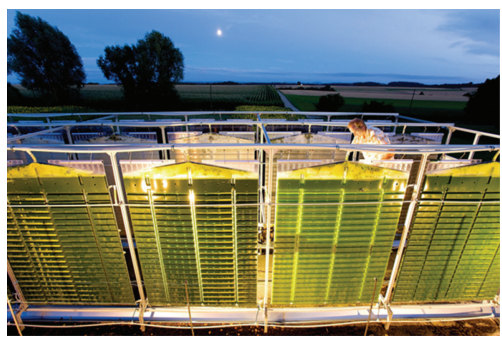

(a)

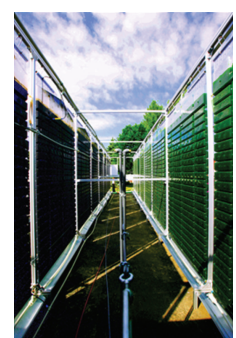

(b)

FIgURE 2: Flat panel airlift photobioreactor designed for low energy consumption (Subitec GmbH).

is essential for downstream treatment and it accounts for approximately $20-30 \%$ of total production cost [44]. The challenge in harvesting is due to the similarity between the density of algal cells and the growth medium, which are in the range of approximately $1080-1110 \mathrm{~kg} \mathrm{~m}^{-3}$ and $1030 \mathrm{~kg} \mathrm{~m}^{-3}$, respectively. Additionally, the dilute cell concentration of $0.5-5 \mathrm{~g} \mathrm{~L}^{-1}$, combined with a negative zeta potential and a minuscule cell diameter of $2-200 \mu \mathrm{m}$ [45] presents further obstacles for effective separation.

Common technologies employed for harvesting are flocculation, flotation, centrifugation, and filtration. Flotation and flocculation could be classed as pretreatment because they are used to aid filtration or centrifugation by increasing concentration via floc formation, consequently reducing the harvesting unit feed quantity. Gravity settling is also an option, but at settling rates between 0.1 and $2.6 \mathrm{~cm} \mathrm{~h}^{-1}$, its prospects are limited for large-scale continuous operation [46]. Flocculation agents such as salts of iron (ferric chloride/sulphate) or aluminium (aluminium sulphate) are already used and their effectiveness can be enhanced by $\mathrm{pH}$ adjustment [47]. Similarly, biologically sourced flocculants, such as chitosan, have shown good performance as harvesting agents [48]. The consequence of using flocculants on downstream processing has not yet been investigated and its effect on product extraction and quality is unknown. Furthermore, the cost of flocculants for a global scale algae industry is too high and it is only applicable to freshwater species because there is a higher proportion of cell charge masking in saline conditions. In this instance, flotation may be a more effective method [44].

The slurry concentration of the primary harvesting method using air flotation or flocculation is $10-20 \mathrm{~g} \mathrm{~L}^{-1}$, but to achieve a concentration of $100-200 \mathrm{~g} \mathrm{~L}^{-1}$, secondary treatment such as filtration or centrifugation is required [49]. Filtration is only feasible when employed for harvesting filamentous or large diameter cells. A frequent problem is that filter screen clogging from compressible cakes requires repeated backwashing, consequently limiting filtration productivity. The power consumption of filtration equipment operating in algae harvesting could be anywhere between 0.3 and $2 \mathrm{kWh} \mathrm{m}^{-3}$ [44]. On the other hand, centrifugation can achieve a high concentration factor of over $95 \%$ by inducing an artificial gravitation field and decreasing separating time substantially. However, centrifuges for largescale processing are expensive to maintain and operate. Emphasis is also placed on construction materials when operated in saline or brackish media. Furthermore, an energy input of $3000 \mathrm{kWh}$ ton ${ }^{-1}$ of processed algae [50] and a power consumption of $1 \mathrm{~kW} \mathrm{~h} \mathrm{~m}^{-3}$ render centrifugation expensive. Emerging technologies such as ultrasonic aggregation and auto bio-flocculation offer a promising outlook for algal mass harvesting but they are still in their infancy and it will take some time for them to be developed for large-scale processing $[51,52]$.

4.3. Extraction. Harvesting is typically followed by drying to obtain biomass with an even higher cell concentration and lower moisture content. Dried biomass is easier to process downstream as the presence of water can hinder the reaction and drying also preserves the harvested algae for storage. Drying can be achieved by natural means in regions with low humidity and high temperature, but in areas lacking these atmospheric conditions, dryers are employed to support 
rapid processing. In order to dry algal sludge, a heat source, agitation to expose moist material, and the removal of evaporated water are necessary. These are achieved by using dryers (rotary, flash, disk, and cascade) or superheated steam. Drying is the most energy intensive process and accounts for more than $50 \%$ of the total energy requirement of the algae oil extraction process [53]. The energy demand for drying is met by fossil fuels; hence a more sustainable method for drying is required to eliminate the negative energy balance of algae biofuel processing [54].

To facilitate the extraction of the intracellular material, the harvested cells are disrupted using a homogeniser or bead milling. These technologies have been employed successfully for large-scale processing [55] and the energy consumption of homogenisers and bead mills is in the range of $1.5-2 \mathrm{kWh}$ per $\mathrm{m}^{3}$ of processed liquid [45]. Mechanical techniques are preferred over nonmechanical ones to avoid contamination and scaling up these units usually results in lower operating cost from efficient pump performance. Once ruptured, more than $95 \%$ of cellular material can be released and the disrupted cells are subjected to a combination of solvents to extract the required products. Typically, the Bligh and Dyer [56] method tends to work favourably for the extraction of lipids, but the extent of extraction is dictated by the algal strain. Thus, the addition of cosolvents is sometimes necessary.

Recently, supercritical $\mathrm{CO}_{2}$ has gained attention as a means of extracting intracellular material from microalgae. The use of $\mathrm{CO}_{2}$ is widespread in the food and pharmaceutical industries. It is already used commercially for coffee decaffeination and for degreasing crisps [57]. The application of $\mathrm{CO}_{2}$ as a solvent for the extraction of lipids is a sought-after method due to its environmentally benign nature, moderate critical parameters, low toxicity, ease of downstream separation, and possibility of fractioning the products [58]. However, results so far have failed to identify the optimal extraction method: liquid solvents, or $\mathrm{SC}-\mathrm{CO}_{2}$. Further investigation is necessary to explore their scale-up potential and economic viability [59].

Reliable information on costs for individual processes is unavailable because it depends on the process route, the algal species, the costing methodology, and the by-products generated. Sun et al. [42] collated costing information for TAG production from selected studies and found the lowest and highest production cost of US $\$ 0.24 \mathrm{~L}^{-1}$ and US $\$ 11.25 \mathrm{~L}^{-1}$, respectively. The average cost was calculated as US $\$ 5.02 \mathrm{~L}^{-1}$ and the lowest cost was predicted by Solix based on a future process route that accounts for improved extraction, dewatering, and harvesting, thus resulting in energy savings and better system integration.

Although the concept and technology of biofuels production from algae offer a potential solution to climate change, the technology to process at a large scale has not yet been developed. The challenges to produce products and commodities that are competitive with those derived from fossil fuels and land crops are enormous. The essential feature in all manufacturing process is scalability. Renewable energy companies in this field and developers of biofuel processes for commercial quantities seek high efficiency, reproducibility, and predictability, while minimising process scope and overall cost. The significant cost components of algae fuel are photobioreactors and the cost of harvesting. The energy cost to cultivate, pump the water, and circulate, the capital cost to build bioreactors, and the harvesting, drying, and extraction costs are still high. Additionally, simple transfer of existing technology may not be suitable for all processes and it might be worth devising proprietary technology devoted exclusively for algae processing.

4.4. Algae Processing for Fuels. Microalgae can be treated chemically and biochemically to obtain the desired fuel. The processing strategy implemented depends on the coproducts required and feed stock quality. Nonetheless microalgae treatment is an active area of research and the processing strategies identified in Table 2 are being investigated for their potential commercial viability.

4.4.1. Biodiesel. The most common liquid fuel from algae is biodiesel. Fatty Acid Methyl Ester (FAME) or biodiesel is typically produced by a reaction (transesterification) between triglycerides and alcohol (most commonly methanol) at $60-70^{\circ} \mathrm{C}$ and in the presence of an alkaline or acidic homogeneous catalyst at atmospheric pressure. In addition to triglycerides in the lipid fraction, algae oil also contains a substantial quantity of free fatty acids (FFAS) and some moisture. Their occurrence is undesirable for transesterification because in alkaline catalysed reaction, they produce soap and reduce biodiesel yield. In this instance, an acid catalyst is better suited for the purpose as it is able to process low grade feed. However, the reaction time is extremely slow and therefore it is not a preferred option for commercial biodiesel production [64]. As a result, an alkaline catalyst is used, but an upper limit on feed FFA is placed at $0.5 \%$ $(\mathrm{w} / \mathrm{w})$, and feed pretreatment to reduce the amount of FFA and eliminate moisture is required $[65,66]$. Alternatively using a heterogeneous catalyst would offer the advantage of regeneration, reuse, and ease of separation, but the low yield [67] and an exceedingly long reaction time [68] have so far limited its use to laboratories. A biological enzyme such as lipase could in theory offer an environmentally benign and feed-flexible processing route for biodiesel production [69]. However, enzymatic activity is affected by the presence of alcohol, particularly methanol, and it is consequently added stepwise at various reaction points [70] to prevent enzyme inhibition. Furthermore, the enzymes are expensive and the reaction slow when compared to equivalent yield in chemical transesterification. The stringent reaction parameters and sluggish reaction [71] make it an unappealing option for commercial applications [72, 73].

Current processes used for manufacturing biodiesel are not entirely suitable for algae oil. A feasible option is to carry out the reaction at high temperature and pressure. The supercritical transesterification of first and second generation oil by various research groups showed almost complete conversion in reasonable reaction time [74-76]. At supercritical conditions, the reaction can process moisturerich feed with free fatty acids and subsequently eliminate 
TABLE 2: Common processing strategies, outcome and energy content of fuels from obtained from microalgae [16, 17, 31-33].

\begin{tabular}{|c|c|c|c|c|c|c|}
\hline \multirow{3}{*}{ Treatment } & \multicolumn{6}{|c|}{ Fuel type and energy content } \\
\hline & Biodiesel & Diesel & Jet Fuel & Biogas & Bioethanol & Hydrogen \\
\hline & $41 \mathrm{MJ} \mathrm{kg}^{-1}$ & $45.9 \mathrm{MJ} \mathrm{kg}^{-1}$ & $42.8 \mathrm{MJ} \mathrm{kg}^{-1}$ & $9.36 \mathrm{MJ} \mathrm{kg}^{-1}$ & $26.24 \mathrm{MJ} \mathrm{kg}^{-1}$ & $120 \mathrm{MJ} \mathrm{kg}^{-1}$ \\
\hline \multicolumn{7}{|l|}{ Biochemical } \\
\hline Lipase transesterification & $\mathrm{X}$ & & & & & \\
\hline Anaerobic digestion & & & & & $\mathrm{X}$ & \\
\hline Aerobic digestion & & & & $\mathrm{X}$ & & \\
\hline Nutrient stress & & & & & & $\mathrm{X}$ \\
\hline \multicolumn{7}{|l|}{ Thermochemical } \\
\hline Pyrolysis & & $\mathrm{X}$ & $\mathrm{X}$ & & & \\
\hline Transesterification & $\mathrm{X}$ & & & & & \\
\hline Gasification & & & & $\mathrm{X}$ & & $\mathrm{X}$ \\
\hline Liquefaction & & $\mathrm{X}$ & $\mathrm{X}$ & & & \\
\hline
\end{tabular}

pre-treatment process units. Application of catalyst-free supercritical alcohol transesterification is desirable due to feed stock flexibility and the relatively small reactor volume needed to achieve high production rates.

Limited research exists on supercritical biodiesel formation from wet algae paste. A two-step process to hydrolyse triglycerides and produce fatty acid containing solid residue for subsequent supercritical ethanol esterification was investigated by Levine et al. [77]. Not only did the process use moisture-rich paste and generate 100\% yield, it also created a nutrient-rich aqueous phase. Likewise, a onestep process for supercritical transesterification of wet algae paste demonstrated the potential for an energy efficient and economically sound route for biodiesel production [78] by avoiding the energy penalty arising from drying.

Even though algal biodiesel is derived from a renewable source, there are certain fundamental issues with biodiesel that should be addressed prior to large-scale manufacturing. Firstly, biodiesel has poor low temperature properties. The pour point and cloud filter plug point are not within the ASTM specification and therefore biodiesel is susceptible to poor performance in colder weather. To overcome this, a pour point depressant is usually added. Secondly, biodiesel is blended with mineral diesel to compensate for the energy difference between the two as the energy content of biodiesel and mineral diesel is $41 \mathrm{MJ} \mathrm{kg}^{-1}$ and $45.9 \mathrm{MJ} \mathrm{kg}^{-1}$, respectively. Lastly, algal oil contains high proportions of polyunsaturated fatty acids, which results in rapid oxidation, limiting long-term storage [33, 79].

4.4.2. Middle Distillate Hydrocarbons. It might be feasible to convert algae oil directly into green diesel or aviation fuel. Catalytic conversion of second generation oil with hydrogen into paraffins has already been investigated for application in industry [80]. Production of algae-based aviation fuel has attracted a considerable interest from the aviation industry, especially after trials on commercial and military aeroplanes using algae biofuel blend. Information on this topic is scant at the moment as it is still at an early stage, but early studies indicate that catalyst development is an important aspect for the conversion of biological compounds to hydrocarbons [81] and should be prioritised.

4.4.3. Biocrude. Attention must also be drawn towards new methods being investigated, where technoeconomic and energy consumption information is not available. As mentioned before, the typical method for algae-based fuel (biodiesel) production is through the removal and processing of intracellular lipids, which stipulates the use of solvents and the energy demanding process of drying. Reduction in the energy consumption of more than $50 \%$ could be achieved by omitting drying [53]. One such process, which removes the energy penalty from drying of algal biomass for downstream processing, is the hydrothermal treatment of wet algae paste at $200-400^{\circ} \mathrm{C}$. Hydrothermal liquefaction could be used to produce biocrude with energy content similar to that of fossil crude [82] and early research indicates that the process has a positive net energy balance of $45.3 \mathrm{~kJ}$ per $\mathrm{kg}$ of biocrude produced. Unlike crude oil, biocrude requires deoxygenation and denitrogenation to make useful fuels, which is a major challenge since there are over 1000 compounds in biocrude [59].

4.4.4. Bioethanol. Over the years, a significant proportion of research funding and effort has been concentrated towards making transportation fuels from algae. Biodiesel is one such liquid fuel, obtained from just the lipid fraction, but the carbohydrate fraction of algal cellular material can also be converted into bioethanol. Some algae species are capable of producing high levels of lipids, and enzymatic fermentation of residual material after lipid extraction can be used to produce bioethanol [83]. Ethanol is considered the chief biofuel of the world and it can be either blended with gasoline or used as a direct substitute [84]. Unlike other sources of ethanol, severe pretreatment of feed is not necessary as algae lack the presence of complex lignin or hemicellulosebased compounds. Only some degree of cell rupture is required to provide an exit route for the carbohydrates [85]. Bioethanol yield from microalgae is substantially larger than that from the first and second generation bioethanol crops 
[46]. From $10 \mathrm{~g}$ of lipid extracted from microalgae remains, a maximum yield of $3.83 \mathrm{~g}$ of ethanol has been achieved [86]. The energy density of bioethanol is only $66 \%$ that of gasoline, and as a result, automobiles running on bioethanol blend usually have a lower mileage [87]. Microalgae fermentation circumvents the need for concentrated harvesting and, as a consequence, reduces costs. Theoretically, a conversion of $56 \%$ is achievable [88] but this is yet to be realised experimentally. In addition, solid fermentation residue can be used as a fertiliser, as animal feed, or it can be gasified.

4.4.5. Pyrolysis Oil. Dry microalgae treated under atmospheric pressure between $300^{\circ} \mathrm{C}$ and $500^{\circ} \mathrm{C}$ in the absence of oxygen for short duration produce pyrolysis oil, gas, and char. The oil can be used directly as a fuel or as a precursor for upgrading to hydrocarbons. Yields of up to $40 \%$ (dry wt. $\%)$ pyrolysis oil can be obtained [89] and under optimised conditions, the heating value of combustible gases produced is superior to that required for processing [90]. Compared to pyrolysis oil from lignin-based feedstock, microalgae oil has a lower oxygen content, a higher carbon/hydrogen ratio, and a greater energy content [60]. Despite this, the biggest disadvantage of the process is that it requires dry biomass, and as discussed previously, drying is a major energetic bottleneck.

4.4.6. Syngas. The gasification of algae at $800^{\circ} \mathrm{C}-1000^{\circ} \mathrm{C}$ operates via the partial oxidation of algal biomass with oxygen and steam to produce syngas, which is primarily composed of $\mathrm{H}_{2}, \mathrm{CH}_{4}, \mathrm{CO}$, and $\mathrm{CO}_{2}$ Syngas can be either used directly as a fuel or further processed for synthesis of chemicals such as methanol [61]. Hirano et al. [91] showed that after reforming, conditioning, and synthesis, a yield of $64 \%$ methanol per unit of algae biomass gasified is achievable leading to a positive energy balance of 1.1 based on energy produced to energy required for the whole process. Theoretically, gasification has a thermodynamic efficiency of $76 \%$ and the produced gas can recover $92 \%$ of the chemical energy present in the feed [92]. In addition to this, the processed effluent is nutrient rich and can be recycled to sustain algal growth [93]. Although changing the operating and feed conditions can increase gas yield [94] for industrial gasification of algae, further research to develop a suitable catalyst is necessary [95].

4.4.7. Biogas. Anaerobic digestion of high water content biomass $(80-90 \%)$ is ideal for conversion into biogas composed mostly (69-75\%) of methane. Algae biogas production can reclaim equivalent energy to lipid extraction and the minute quantity of sulphurated amino acid production results in negligible hydrogen sulphide (a corrosive gas) formation. Disrupted algae cells are subjected to a three-step anaerobic microbiological decomposition process, initiated by hydrolysis of proteins, carbohydrates, and lipids into soluble sugars. Lipid hydrolysis is slow compared to the other compounds. The sugars are then fermented to volatile fatty acids, alcohol, hydrogen, and carbon dioxide followed by methanogenesis to form methane and carbon dioxide
[96]. The trace metals present in algae have been shown to aid methanogenesis, and nutrient reclamation is achieved in the effluent, which can be recycled for use in a fresh growth medium [97]. However, the presence of nitrogen in microalgae protein releases ammonia, which in turn alters the $\mathrm{pH}$ of the liquid resulting in the inhibition of anaerobic flora. A similar inhibitory effect is observed with the presence of sodium ions at concentrations above $0.5 \mathrm{M}$ [98]. A solution to this problem could be to codigest algae with other biomass. Addition of waste paper to form a 50:50 mixture with algae has shown to increase methane yield resulting from the high carbon/nitrogen ratio [99]. From previous economic modelling investigations [50, 100], it is claimed that additional energy (based on net energy balance) could be generated by anaerobic digestion when combined with carbon and nutrient recycling [18]. Even though biogas from algae is a leading biofuel contender, commercial scale-up and life-cycle analysis show that there are still improvements to be made to increase process efficiency [101].

4.4.8. Hydrogen. Hydrogen is considered the fuel of the future. Microalgae have the natural genetic characteristic necessary to split water using solar energy to produce hydrogen [102]. They are capable of doing this due to the presence of the enzyme hydrogenase, which can convert hydrogen ions produced during photosynthesis into molecular hydrogen. Water splitting also produces oxygen, which inhibits the hydrogenase enzyme implying that hydrogen production is self-limiting [103]. In order to attain extended hydrogen production, the removal of oxygen as it is being produced is necessary. This is achieved by growing algae in normal conditions and then subjecting it to sulphur deprivation resulting in anaerobic conditions during which hydrogen production can be sustained for up to 7 days. It is estimated that this two-step process can theoretically yield $198 \mathrm{~kg}$ hydrogen ha $^{-1}$ day $^{-1}$ [104]. Microalgae use atmospheric carbon dioxide for biomass synthesis and produce a clean and renewable fuel. The true potential of hydrogen from algae is limited by the high costs associated with large-scale photobioreactors and by low photochemical efficiencies.

\section{Algal Biorefinery}

A plethora of algal biofuel companies has appeared (and disappeared) recently, which are addressing the issues related to high production costs. While the number of patents and publications associated with the field has risen sharply, to date no attempt has been made to commercialise these at the required scale. An estimated figure suggests that only a total of US $\$ 307$ and US $\$ 320$ million were invested in algae ventures in 2007 and 2008, respectively [62]. The algae biorefinery concept presents an integrated approach for multiple products manufacturing with the added advantage of utilising all alga components and generating several revenue streams [63]. It offers a "one stop shop" approach for on-site generation of fuels, chemicals, nutrients, fertiliser, and combustible gas. 


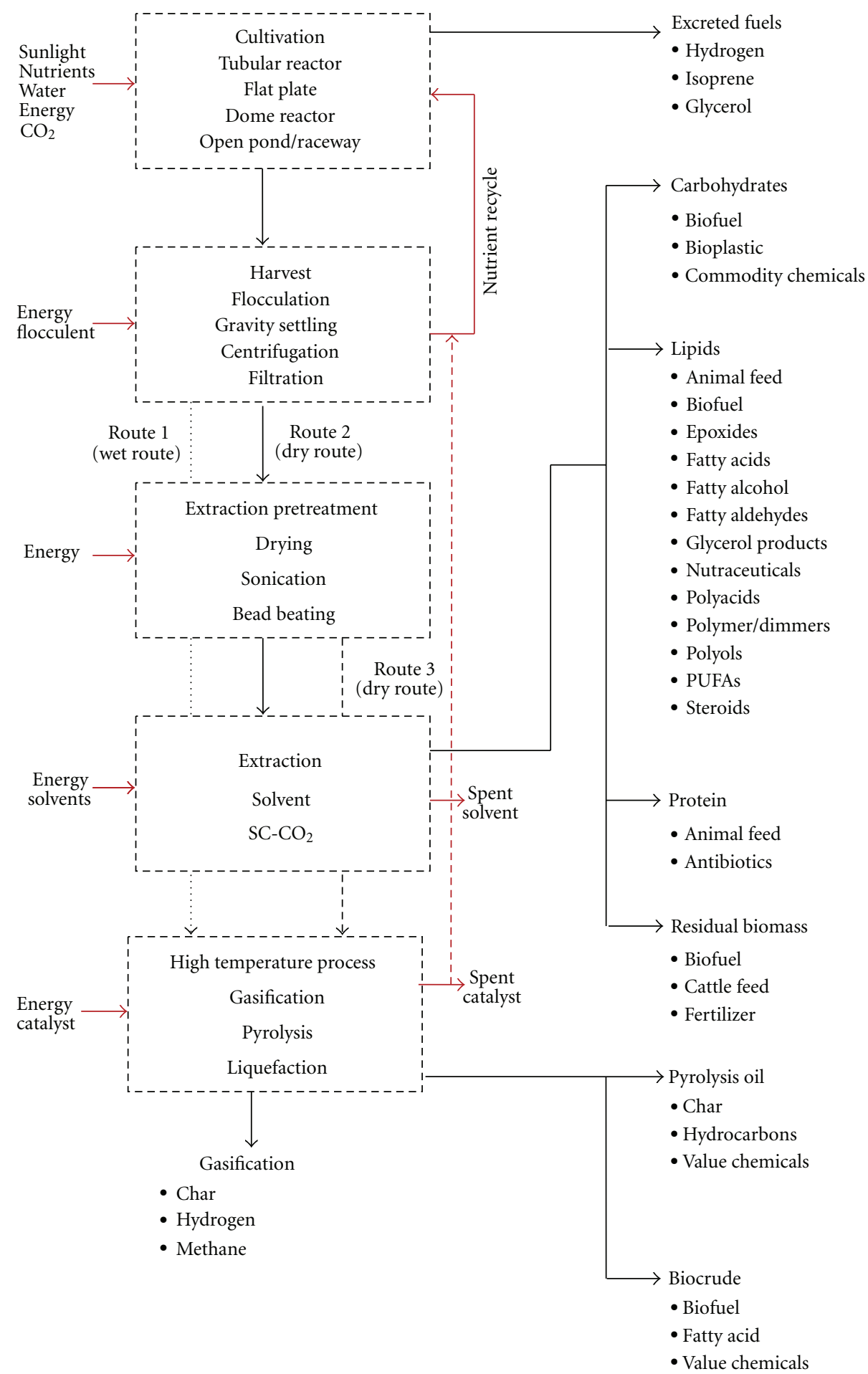

Figure 3: Schematic of algal biorefinery concept [59-63].

Figure 3 shows the general concept of an algal refinery including the processes and products that could be obtained. There are three potential process routes that could be followed for the synthesis of required chemicals. Route 1 and route 3 are relatively new for processing microalgae and their prospects are still being investigated.
The long term scope for algae biofuel lies in the development of an integrated energy park [105] whereby various green technologies function simultaneously to deliver a solution for a global problem. It is conceptually envisaged that such a model can displace fossil fuels and produce liquid biofuels without much impact on the environment. 
In order to accomplish this, scientists, technocrats, venture capitalists, and politicians need to think big. Only in a "Verbundsystem" - an integrated system of energy and material flows as demonstrated by, for example, BASF (Ludwigshafen, Germany) orJurong Island (Singapore)will a biorefinery make sense. This will require a huge effort in the development of downstream processing and separation technologies. Niche markets could initially be served through localised, targeted processes for higher value products (e.g., 1,3 propanediol, vitamins, etc.) and thus form the first phase of realistic investment. Whether in the long run the optimal output of an algal biorefinery is in the intermediate value and intermediate volume domain remains to be seen. Regardless, there is certainly a future in chemicals and fuels from algae provided timely technological advances are made. Ultimately, algae is the only sustainable source of biofuels and biochemicals at present and it is up to the human race to make the most of this available resource and use it efficiently to our advantage sustainably.

\section{Acknowledgments}

Figure 2(a) was acquired from Copyright Thomas Ernsting and Figure 2(b) was acquired from Subitec GmbH. The editing Figures 1(a), 1(b) and 1(c) and Figures 2(a) and 2(b) were performed by Mehul Shewakramani.

\section{References}

[1] S. Solomon, D. Qin, M. Manning et al., Contribution of Working Group I To the Fourth Assessment Report of the Intergovernmental Panel on Climate Change, Cambridge University Press, 2007.

[2] D. J. C. MacKay, "Solar II," in Sustainable Energy -Without the Hot Air, D. J. C. MacKay, Ed., pp. 283-289, UIT Cambridge, Great Britain, UK, 1st edition, 2009.

[3] M. J. Groom, E. M. Gray, and P. A. Townsend, "Biofuels and biodiversity: principles for creating better policies for biofuel production," Conservation Biology, vol. 22, no. 3, pp. 602 609, 2008.

[4] D. Pimentel, A. Marklein, M. A. Toth et al., "Food versus biofuels: environmental and economic costs," Human Ecology, vol. 37, no. 1, pp. 1-12, 2009.

[5] M. Lynas, "The Climate change boundary," in The God Species: How the Planet Can Survive the Age of Humans, M. Lynas, Ed., pp. 85-110, HarperCollins, Great Britain, UK, 1st edition, 2011.

[6] T. Searchinger, R. Heimlich, R. A. Houghton et al., "Use of U.S. croplands for biofuels increases greenhouse gases through emissions from land-use change," Science, vol. 319, no. 5867, pp. 1238-1240, 2008.

[7] G. Peharz, F. Dimroth, and U. Wittstadt, "Solar hydrogen production by water splitting with a conversion efficiency of 18\%," International Journal of Hydrogen Energy, vol. 32, no. 15, pp. 3248-3252, 2007.

[8] S. E. Oh, P. Iyer, M. A. Bruns, and B. E. Logan, "Biological hydrogen production using a membrane bioreactor," Biotechnology and Bioengineering, vol. 87, no. 1, pp. 119-127, 2004.

[9] K. Skjånes, P. Lindblad, and J. Muller, "BioCO 2 -a multidisciplinary, biological approach using solar energy to capture $\mathrm{CO}_{2}$ while producing $\mathrm{H}_{2}$ and high value products," Biomolecular Engineering, vol. 24, no. 4, pp. 405-413, 2007.

[10] O. Kruse and B. Hankamer, "Microalgal hydrogen production," Current Opinion in Biotechnology, vol. 21, no. 3, pp. 238-243, 2010.

[11] R. E. Blankenship, D. M. Tiede, J. Barber et al., "Comparing photosynthetic and photovoltaic efficiencies and recognizing the potential for improvement," Science, vol. 332, no. 6031, pp. 805-809, 2011.

[12] B. Esper, A. Badura, and M. Rögner, "Photosynthesis as a power supply for (bio-)hydrogen production," Trends in Plant Science, vol. 11, no. 11, pp. 543-549, 2006.

[13] J. A. Cracknell, K. A. Vincent, M. Ludwig, O. Lenz, B. Friedrich, and F. A. Armstrong, "Enzymatic oxidation of $\mathrm{H}_{2}$ in atmospheric $\mathrm{O}_{2}$ : the electrochemistry of energy generation from trace $\mathrm{H}_{2}$ by aerobic microorganisms," Journal of the American Chemical Society, vol. 130, no. 2, pp. 424-425, 2008.

[14] O. Kruse, J. Rupprecht, J. H. Mussgnug, G. C. Dismukes, and B. Hankamer, "Photosynthesis: a blueprint for solar energy capture and biohydrogen production technologies," Photochemical and Photobiological Sciences, vol. 4, no. 12, pp. 957-970, 2005.

[15] T. Faunce, "Artificial photosynthesis: feeding and fuelling the future," Australasian Science, vol. 32, no. 10, pp. 20-22, 2011.

[16] L. L. Beer, E. S. Boyd, J. W. Peters, and M. C. Posewitz, "Engineering algae for biohydrogen and biofuel production," Current Opinion in Biotechnology, vol. 20, no. 3, pp. 264-271, 2009.

[17] Y. Chisti, "Biodiesel from microalgae beats bioethanol," Trends in Biotechnology, vol. 26, no. 3, pp. 126-131, 2008.

[18] E. Stephens, I. L. Ross, J. H. Mussgnug et al., "Future prospects of microalgal biofuel production systems," Trends in Plant Science, vol. 15, no. 10, pp. 554-564, 2010.

[19] A. Melis, L. Zhang, M. Forestier, M. L. Ghirardi, and M. Seibert, "Sustained photobiological hydrogen gas production upon reversible inactivation of oxygen evolution in the green alga Chlamydomonas reinhardtii," Plant Physiology, vol. 122, no. 1, pp. 127-135, 2000.

[20] A. Doebbe, M. Keck, M. La Russa et al., "The interplay of proton, electron, and metabolite supply fors photosynthetic $\mathrm{H}_{2}$ production in Chlamydomonas reinhardtii," Journal of Biological Chemistry, vol. 285, no. 39, pp. 30247-30260, 2010.

[21] C. Faraloni, A. Ena, C. Pintucci, and G. Torzillo, "Enhanced hydrogen production by means of sulfur-deprived Chlamydomonas reinhardtii cultures grown in pretreated olive mill wastewater," International Journal of Hydrogen Energy, vol. 36, no. 10, pp. 5920-5931, 2011.

[22] S. Kosourov, E. Patrusheva, M. L. Ghirardi, M. Seibert, and A. Tsygankov, "A comparison of hydrogen photoproduction by sulfur-deprived Chlamydomonas reinhardtii under different growth conditions," Journal of Biotechnology, vol. 128, no. 4, pp. 776-787, 2007.

[23] B. Hankamer, F. Lehr, J. Rupprecht, J. H. Mussgnug, C. Posten, and $\mathrm{O}$. Kruse, "Photosynthetic biomass and $\mathrm{H}_{2}$ production by green algae: from bioengineering to bioreactor scale-up," Physiologia Plantarum, vol. 131, no. 1, pp. 10-21, 2007.

[24] Encyclopædia Britannica Online, s. v., "blue-green algae", 2012, http://www.britannica.com/EBchecked/topic/70231/ blue-green-algae.

[25] D. Dutta, D. De, S. Chaudhuri, and S. K. Bhattacharya, "Hydrogen production by Cyanobacteria," Microbial Cell Factories, vol. 4, article 36, 2005. 
[26] M. Brenner, L. Bildsten, F. Dyson et al., "Engineering microorganisms for energy production," Tech. Rep. JSR-05300, The MITRE Corporation JASON Program Office, 2006.

[27] A. Parmar, N. K. Singh, A. Pandey, E. Gnansounou, and D. Madamwar, "Cyanobacteria and microalgae: a positive prospect for biofuels," Bioresource Technology, vol. 102, no. 22, pp. 10163-10172, 2011.

[28] C. M. Yeager, C. E. Milliken, C. E. Bagwell, L. Staples, P. A. Berseth, and H. T. Sessions, "Evaluation of experimental conditions that influence hydrogen production among heterocystous Cyanobacteria," International Journal of Hydrogen Energy, vol. 36, no. 13, pp. 7487-7499, 2011.

[29] A. Bandyopadhyay, J. Stöckel, H. Min, L. A. Sherman, and H. B. Pakrasi, "High rates of photobiological $\mathrm{H}_{2}$ production by a cyanobacterium under aerobic conditions," Nature Communications, vol. 1, no. 9, article 139, 2010.

[30] S. A. Angermayr, K. J. Hellingwerf, P. Lindblad, and M. J. Teixeira de, "Energy biotechnology with cyanobacteria," Current Opinion in Biotechnology, vol. 20, no. 3, pp. 257-263, 2009.

[31] J. I. Hileman, R. W. Stratton, and P. E. Donohoo, "Energy content and alternative jet fuel viability," Journal of Propulsion and Power, vol. 26, no. 6, pp. 1184-1196, 2010.

[32] T. L. Kelly-Yong, K. T. Lee, A. R. Mohamed, and S. Bhatia, "Potential of hydrogen from oil palm biomass as a source of renewable energy worldwide," Energy Policy, vol. 35, no. 11, pp. 5692-5701, 2007.

[33] L. Brennan and P. Owende, "Biofuels from microalgaeA review of technologies for production, processing, and extractions of biofuels and co-products," Renewable and Sustainable Energy Reviews, vol. 14, no. 2, pp. 557-577, 2010.

[34] D. C. Ducat, J. C. Way, and P. A. Silver, "Engineering cyanobacteria to generate high-value products," Trends in Biotechnology, vol. 29, no. 2, pp. 95-103, 2011.

[35] O. Pulz and W. Gross, "Valuable products from biotechnology of microalgae," Applied Microbiology and Biotechnology, vol. 65, no. 6, pp. 635-648, 2004.

[36] R. H. Wijffels and M. J. Barbosa, "An outlook on microalgal biofuels," Science, vol. 329, no. 5993, pp. 796-799, 2010.

[37] http://www.ecoduna.com/projects/ecoduna-vattenfall/.

[38] J. Sheehan, T. Dunahay, J. Benemann, and P. Roessler, "A look back at the U.S. department of energy's aquatic species program: biodiesel from algae," Tech. Rep. NREL/TP58024190, 1998.

[39] C. Posten, "Design principles of photo-bioreactors for cultivation of microalgae," Engineering in Life Sciences, vol. 9, no. 3, pp. 165-177, 2009.

[40] B. Tamburic, F. W. Zemichael, P. Crudge, G. C. Maitland, and K. Hellgardt, "Design of a novel flat-plate photobioreactor system for green algal hydrogen production," International Journal of Hydrogen Energy, vol. 36, no. 11, pp. 6578-6591, 2011.

[41] Oilgae, Cost-Reduction Strategies Developed by Various Photobioreactor Manufacturers, 2012, http://www.oilgae .com/ref/downloads/cost-reduction-strat-egy-PBR.pdf.

[42] A. Sun, R. Davis, M. Starbuck, A. Ben-Amotz, R. Pate, and P. T. Pienkos, "Comparative cost analysis of algal oil production for biofuels," Energy, vol. 36, no. 8, pp. 5169-5179, 2011.

[43] N. H. Norsker, M. J. Barbosa, M. H. Vermuë, and R. H. Wijffels, "Microalgal production-a close look at the economics," Biotechnology Advances, vol. 29, no. 1, pp. 24-27, 2011.

[44] E. Molina Grima, E. H. Belarbi, F. G. Acién Fernández, A. Robles Medina, and Y. Chisti, "Recovery of microalgal biomass and metabolites: process options and economics," Biotechnology Advances, vol. 20, no. 7-8, pp. 491-515, 2003.

[45] H. C. Greenwell, L. M. L. Laurens, R. J. Shields, R. W. Lovitt, and K. J. Flynn, "Placing microalgae on the biofuels priority list: a review of the technological challenges," Journal of the Royal Society Interface, vol. 7, no. 46, pp. 703-726, 2010.

[46] S. K. Choi, J. Y. Lee, D. Y. Kwon, and K. J. Cho, "Settling characteristics of problem algae in the water treatment process," Water Science and Technology, vol. 53, no. 7, pp. 113-119, 2006.

[47] S. J. Lee, S. B. Kim, J. E. Kim, G. S. Kwon, B. D. Yoon, and H. M. Oh, "Effects of harvesting method and growth stage on the flocculation of the green alga Botryococcus braunii," Letters in Applied Microbiology, vol. 27, no. 1, pp. 14-18, 1998.

[48] J. Morales, J. de la Noüe, and G. Picard, "Harvesting marine microalgae species by chitosan flocculation," Aquacultural Engineering, vol. 4, no. 4, pp. 257-270, 1985.

[49] P. M. Schenk, S. R. Thomas-Hall, E. Stephens et al., "Secong generation biofuels: high-effeciency microalgae for biodiesel production," Bioenergy Research, vol. 1, no. 1, pp. 20-43, 2008.

[50] J. R. Benemann and W. J. Oswald, "Systems and economic analysis of microalgae ponds for conversion of $\mathrm{CO}_{2}$ to biomass," Tech. Rep., 1996.

[51] R. Bosma, W. A. Van Spronsen, J. Tramper, and R. H. Wijffels, "Ultrasound, a new separation technique to harvest microalgae," Journal of Applied Phycology, vol. 15, no. 2-3, pp. 143-153, 2003.

[52] A. K. Lee, D. M. Lewis, and P. J. Ashman, "Microbial flocculation, a potentially low-cost harvesting technique for marine microalgae for the production of biodiesel," Journal of Applied Phycology, vol. 21, no. 5, pp. 559-567, 2009.

[53] L. Lardon, A. Hélias, B. Sialve, J. P. Steyer, and O. Bernard, "Life-cycle assessment of biodiesel production from microalgae," Environmental Science and Technology, vol. 43, no. 17, pp. 6475-6481, 2009.

[54] K. Sander and G. S. Murthy, "Life cycle analysis of algae biodiesel," International Journal of Life Cycle Assessment, vol. 15, no. 7, pp. 704-714, 2010.

[55] Y. Chisti and M. Moo-Young, "Disruption of microbial cells for intracellular products," Enzyme and Microbial Technology, vol. 8, no. 4, pp. 194-204, 1986.

[56] E. G. Bligh and W. J. Dyer, "A rapid method of total lipid extraction and purification," Canadian Journal of Biochemistry and Physiology, vol. 37, no. 8, pp. 911-917, 1959.

[57] R. S. Mohamed and G. A. Mansoori, The Use of Supercritical Fluid Extraction Technology in Food Processing, Featured Article_Food Technology Magazine, The World Markets Research Center, London, UK, 2002.

[58] F. Sahena, I. S. M. Zaidul, S. Jinap et al., "Application of supercritical $\mathrm{CO}_{2}$ in lipid extraction-a review," Journal of Food Engineering, vol. 95, no. 2, pp. 240-253, 2009.

[59] M. K. Lam and K. T. Lee, "Microalgae biofuels: a critical review of issues, problems and the way forward," Biotechnology Advances, vol. 30, no. 3, pp. 673-690, 2012.

[60] S. Venkata Mohan, M. Prathima Devi, G. Mohanakrishna, N. Amarnath, M. Lenin Babu, and P. N. Sarma, "Potential of mixed microalgae to harness biodiesel from ecological waterbodies with simultaneous treatment," Bioresource Technology, vol. 102, no. 2, pp. 1109-1117, 2011.

[61] S. Amin, "Review on biofuel oil and gas production processes from microalgae," Energy Conversion and Management, vol. 50, no. 7, pp. 1834-1840, 2009. 
[62] B. Subhadra and M. Edwards, "An integrated renewable energy park approach for algal biofuel production in United States," Energy Policy, vol. 38, no. 9, pp. 4897-4902, 2010.

[63] P. M. Foley, E. S. Beach, and J. B. Zimmerman, "Algae as a source of renewable chemicals: opportunities and challenges," Green Chemistry, vol. 13, no. 6, pp. 1399-1405, 2011.

[64] E. Lotero, Y. Liu, D. E. Lopez, K. Suwannakarn, D. A. Bruce, and J. G. Goodwin, "Synthesis of biodiesel via acid catalysis," Industrial and Engineering Chemistry Research, vol. 44, no. 14, pp. 5353-5363, 2005.

[65] E. A. Ehimen, Z. F. Sun, and C. G. Carrington, "Variables affecting the in situ transesterification of microalgae lipids," Fuel, vol. 89, no. 3, pp. 677-684, 2010.

[66] L. C. Meher, D. Vidya Sagar, and S. N. Naik, "Technical aspects of biodiesel production by transesterification-a review," Renewable and Sustainable Energy Reviews, vol. 10, no. 3, pp. 248-268, 2006.

[67] A. Carrero, G. Vicente, R. Rodríguez, M. Linares, and G. L. Del Peso, "Hierarchical zeolites as catalysts for biodiesel production from Nannochloropsis microalga oil," Catalysis Today, vol. 167, no. 1, pp. 148-153, 2011.

[68] E. S. Umdu, M. Tuncer, and E. Seker, "Transesterification of Nannochloropsis oculata microalga's lipid to biodiesel on $\mathrm{Al}_{2} \mathrm{O}_{3}$ supported $\mathrm{CaO}$ and $\mathrm{MgO}$ catalysts," Bioresource Technology, vol. 100, no. 11, pp. 2828-2831, 2009.

[69] S. Shah, S. Sharma, and M. N. Gupta, "Biodiesel preparation by lipase-catalyzed transesterification of Jatropha oil," Energy and Fuels, vol. 18, no. 1, pp. 154-159, 2004.

[70] M. Balat and H. Balat, "A critical review of bio-diesel as a vehicular fuel," Energy Conversion and Management, vol. 49, no. 10, pp. 2727-2741, 2008.

[71] A. Demirbas, "Comparison of transesterification methods for production of biodiesel from vegetable oils and fats," Energy Conversion and Management, vol. 49, no. 1, pp. 125$130,2008$.

[72] U. Schuchardt, R. Sercheli, and R. M. Vargas, "Transesterification of vegetable oils: a review," Journal of the Brazilian Chemical Society, vol. 9, no. 3, pp. 199-210, 1998.

[73] J. M. Marchetti, V. U. Miguel, and A. F. Errazu, "Possible methods for biodiesel production," Renewable and Sustainable Energy Reviews, vol. 11, no. 6, pp. 1300-1311, 2007.

[74] N. Aimaretti, D. L. Manuale, V. M. Mazzieri, C. R. Vera, and J. C. Yori, "Batch study of glycerol decomposition in one-stage supercritical production of biodiesel," Energy and Fuels, vol. 23, no. 2, pp. 1076-1080, 2009.

[75] V. F. Marulanda, G. Anitescu, and L. L. Tavlarides, "Biodiesel fuels through a continuous flow process of chicken fat supercritical transesterification," Energy and Fuels, vol. 24, no. 1, pp. 253-260, 2010.

[76] Y. Warabi, D. Kusdiana, and S. Saka, "Biodiesel fuel from vegetable oil by various supercritical alcohols," Applied Biochemistry and Biotechnology, vol. 115, no. 1-3, pp. 793801, 2004.

[77] R. B. Levine, T. Pinnarat, and P. E. Savage, "Biodiesel production from wet algal biomass through in situ lipid hydrolysis and supercritical transesterification," Energy and Fuels, vol. 24, no. 9, pp. 5235-5243, 2010.

[78] P. D. Patil, V. G. Gude, A. Mannarswamy et al., "Optimization of direct conversion of wet algae to biodiesel under supercritical methanol conditions," Bioresource Technology, vol. 102, no. 1, pp. 118-122, 2011.

[79] G. Knothe, "Improving biodiesel fuel properties by modifying fatty ester composition," Energy and Environmental Science, vol. 2, no. 7, pp. 759-766, 2009.
[80] T. Kalnes, T. Marker, and D. R. Shonnard, "Green diesel: a second generation biofuel," International Journal of Chemical Reactor Engineering, vol. 5, article A48, 2007.

[81] N. H. Tran, J. R. Bartlett, G. S. K. Kannangara, A. S. Milev, H. Volk, and M. A. Wilson, "Catalytic upgrading of biorefinery oil from micro-algae,” Fuel, vol. 89, no. 2, pp. 265-274, 2010.

[82] T. M. Brown, P. Duan, and P. E. Savage, "Hydrothermal liquefaction and gasification of Nannochloropsis sp," Energy and Fuels, vol. 24, no. 6, pp. 3639-3646, 2010.

[83] R. Harun and M. K. Danquah, "Enzymatic hydrolysis of microalgal biomass for bioethanol production," Chemical Engineering Journal, vol. 168, no. 3, pp. 1079-1084, 2011.

[84] S. I. Mussatto, G. Dragone, P. M. R. Guimarães et al., "Technological trends, global market, and challenges of bioethanol production," Biotechnology Advances, vol. 28, no. 6, pp. 817-830, 2010.

[85] R. P. John, G. S. Anisha, K. M. Nampoothiri, and A. Pandey, "Micro and macroalgal biomass: a renewable source for bioethanol," Bioresource Technology, vol. 102, no. 1, pp. 186193, 2011.

[86] R. Harun, M. K. Danquah, and G. M. Forde, "Microalgal biomass as a fermentation feedstock for bioethanol production," Journal of Chemical Technology and Biotechnology, vol. 85, no. 2, pp. 199-203, 2010.

[87] J. R. Regalbuto, "Engineering: cellulosic biofuels-got gasoline?” Science, vol. 325, no. 5942, pp. 822-824, 2009.

[88] A. Hirano, R. Ueda, S. Hirayama, and Y. Ogushi, " $\mathrm{CO}_{2}$ fixation and ethanol production with microalgal photosynthesis and intracellular anaerobic fermentation," Energy, vol. 22, no. 2-3, pp. 137-142, 1997.

[89] I. V. Babich, M. van der Hulst, L. Lefferts, J. A. Moulijn, P. O'Connor, and K. Seshan, "Catalytic pyrolysis of microalgae to high-quality liquid bio-fuels," Biomass and Bioenergy, vol. 35, no. 7, pp. 3199-3207, 2011.

[90] S. Grierson, V. Strezov, G. Ellem, R. Mcgregor, and J. Herbertson, "Thermal characterisation of microalgae under slow pyrolysis conditions," Journal of Analytical and Applied Pyrolysis, vol. 85, no. 1-2, pp. 118-123, 2009.

[91] A. Hirano, K. Hon-Nami, S. Kunito, M. Hada, and Y. Ogushi, "Temperature effect on continuous gasification of microalgal biomass: theoretical yield of methanol production and its energy balance," Catalysis Today, vol. 45, no. 1-4, pp. 399404, 1998.

[92] Y. Calzavara, C. Joussot-Dubien, G. Boissonnet, and S. Sarrade, "Evaluation of biomass gasification in supercritical water process for hydrogen production," Energy Conversion and Management, vol. 46, no. 4, pp. 615-631, 2005.

[93] T. Minowa and S. Sawayama, "A novel microalgal system for energy production with nitrogen cycling," Fuel, vol. 78, no. 10, pp. 1213-1215, 1999.

[94] Q. Guan, P. E. Savage, and C. Wei, "Gasification of alga Nannochloropsis sp. in supercritical water," The Journal of Supercritical Fluids, vol. 61, pp. 139-145, 2012.

[95] A. G. Chakinala, D. W. F. Brilman, W. P. M. Van Swaaij, and S. R. A. Kersten, "Catalytic and non-catalytic supercritical water gasification of microalgae and glycerol," Industrial and Engineering Chemistry Research, vol. 49, no. 3, pp. 1113-1122, 2010.

[96] K. B. Cantrell, T. Ducey, K. S. Ro, and P. G. Hunt, "Livestock waste-to-bioenergy generation opportunities," Bioresource Technology, vol. 99, no. 17, pp. 7941-7953, 2008. 
[97] S. M. Phang, M. S. Miah, B. G. Yeoh, and M. A. Hashim, "Spirulina cultivation in digested sago starch factory wastewater," Journal of Applied Phycology, vol. 12, no. 3-5, pp. 395400, 2000.

[98] B. Sialve, N. Bernet, and O. Bernard, "Anaerobic digestion of microalgae as a necessary step to make microalgal biodiesel sustainable," Biotechnology Advances, vol. 27, no. 4, pp. 409416, 2009.

[99] H. W. Yen and D. E. Brune, "Anaerobic co-digestion of algal sludge and waste paper to produce methane," Bioresource Technology, vol. 98, no. 1, pp. 130-134, 2007.

[100] J. C. Weissman and R. P. Goebel, "Design and analysis of microalgal open pond systems for the purpose of producing fuels: a subcontract report," Tech. Rep., Solar Energy Research Institute, Golden, Colo, USA, 1987.

[101] P. Collet, A. Hélias Arnaud, L. Lardon, M. Ras, R. A. Goy, and J. P. Steyer, "Life-cycle assessment of microalgae culture coupled to biogas production," Bioresource Technology, vol. 102, no. 1, pp. 207-214, 2011.

[102] M. L. Ghirardi, L. Zhang, J. W. Lee et al., "Microalgae: a green source of renewable $\mathrm{H}_{2}$," Trends in Biotechnology, vol. 18, no. 12, pp. 506-511, 2000.

[103] B. Tamburic, F. W. Zemichael, G. C. Maitland, and K. Hellgardt, "Parameters affecting the growth and hydrogen production of the green alga Chlamydomonas reinhardtii," International Journal of Hydrogen Energy, vol. 36, no. 13, pp. 7872-7876, 2011.

[104] A. Melis and T. Happe, "Hydrogen production. Green algae as a source of energy," Plant Physiology, vol. 127, no. 3, pp. 740-748, 2001.

[105] B. G. Subhadra, "Sustainability of algal biofuel production using integrated renewable energy park (IREP) and algal biorefinery approach," Energy Policy, vol. 38, no. 10, pp. 5892-5901, 2010. 

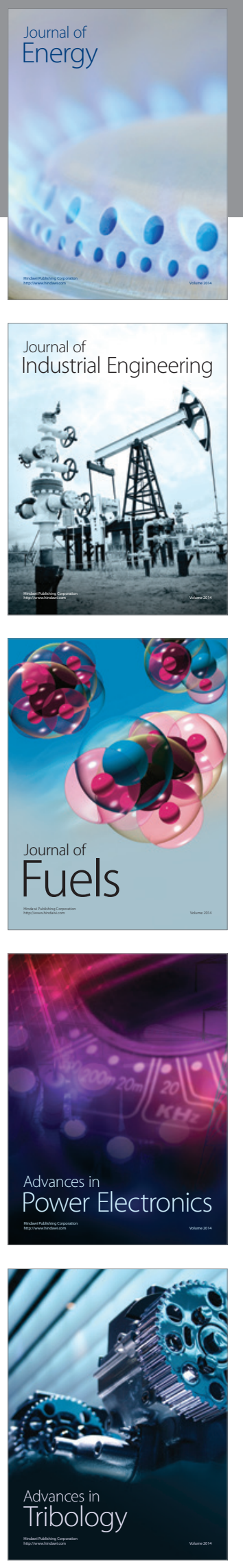
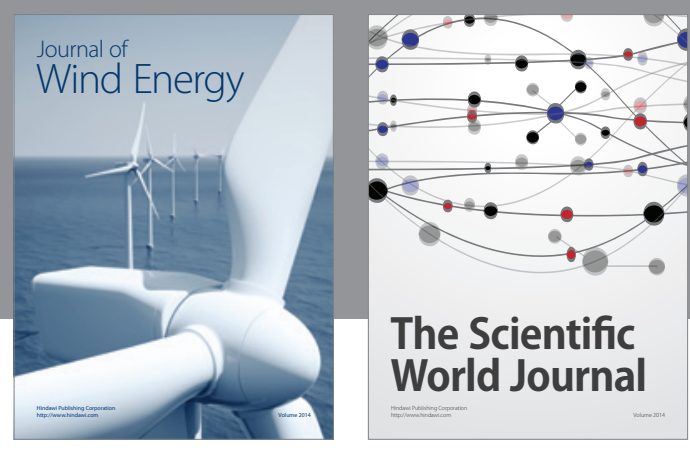

The Scientific World Journal

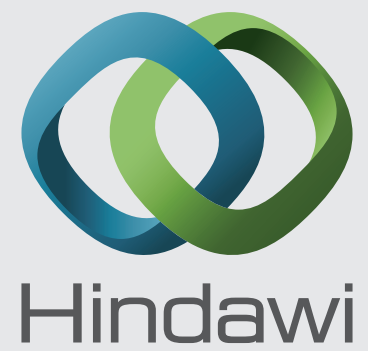

Submit your manuscripts at http://www.hindawi.com
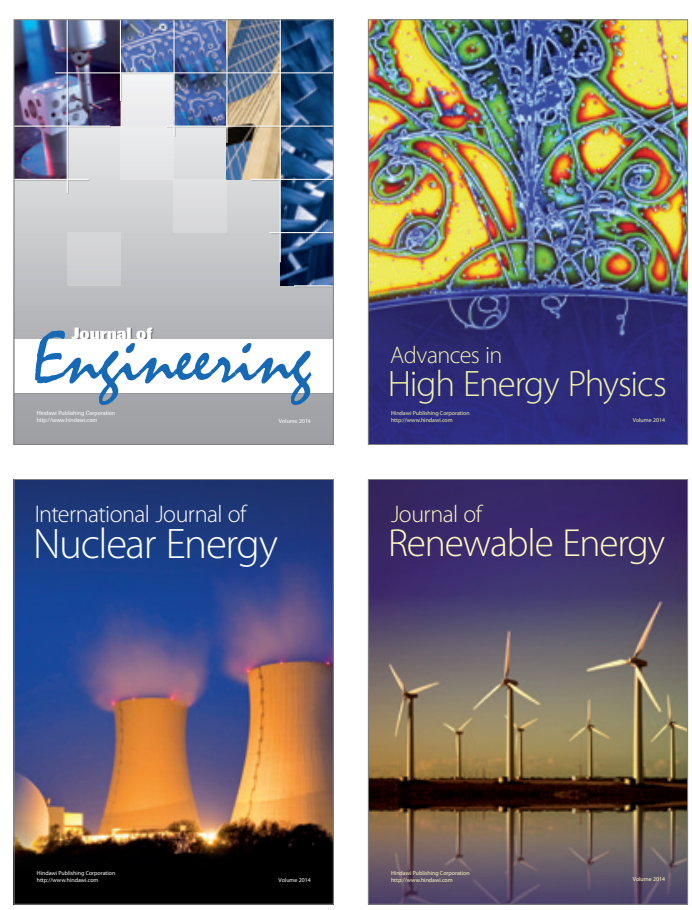

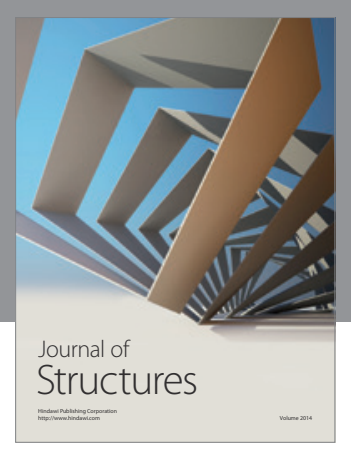

Rotating
Mechinery
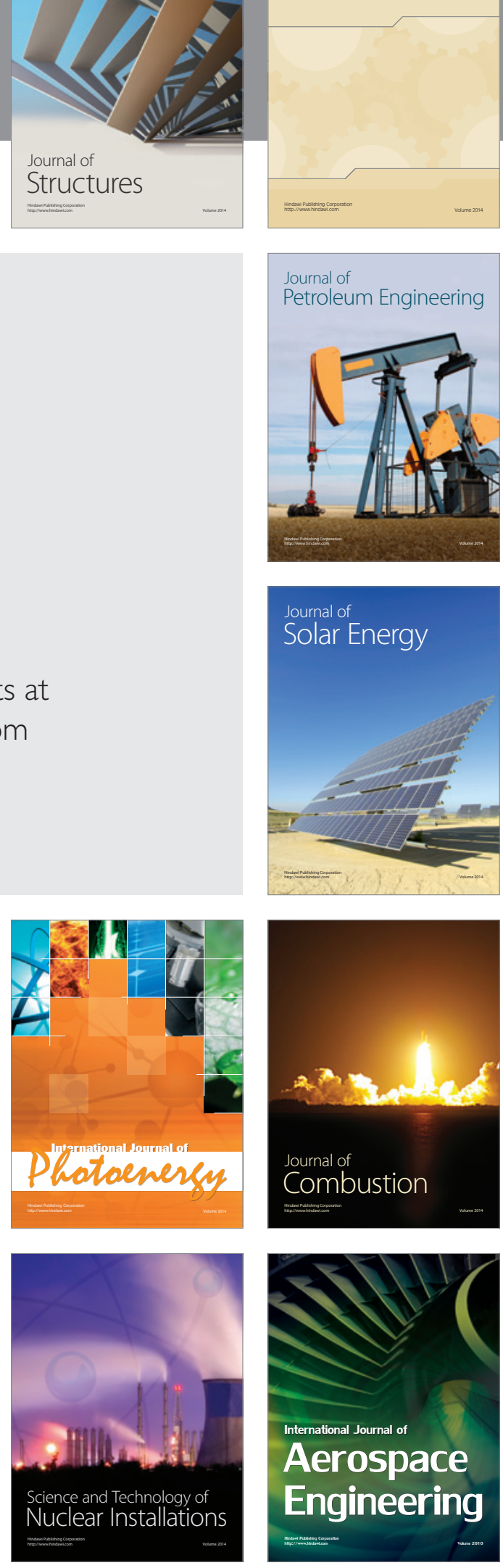